\title{
土中型プレキャストコンクリートガード フェンスの衝撃模型実験と衝撃応答解析
}

\author{
小林一隆 $^{1} \cdot$ 奥田将樹 $^{2} \cdot$ 石川信隆 $^{3} \cdot$ 太田俊昭 $^{4}$ \\ ${ }^{1}$ 正会員 日本サミコン株式会社 技術部研究開発課（广950新潟市弁天橋通1-8-23） \\ 2学生会員 防衛大学校 理工学研究科学生 (广239横須賀市走水1-10-20) \\ ${ }^{3}$ 正会員 工博 防衛大学校教授 土木工学科（广 239 横須賀市走水 $1-10-20$ ) \\ ${ }^{4}$ 正会員 工博 九州大学教授 工学部建設都市工学科（广812福岡市東区箱崎6-10-1)
}

\begin{abstract}
本研究は, 車両の衝突による土中型プレキャストコンクリートガードフェンス（PG F）の衝撃举動を明らかにすること を目的とし，まず P C 銅棒によって連結された土中型P G F を対象として, 振り子式衝慗実験装置を用いた衝撃模型実験を 行い, その緩衝効果と衝撃挙動を明らかにした. 次に, 剛体ばねモデルを用いた衝撃応答解析を行い, 土中型P G F 衝擊 挙動および衝突体の受ける加速度について衝突模型実験結果との比較検討を試み, 最後に, 実際のP G F の適用性につい ても検討したものである.
\end{abstract}

Key Words : precast concrete guard fense,impact test,impact response analysis

\section{1. 緒言}

近年，交通量の増加や車両の大型化および高速化に 伴い, 車両の路外および対向車線への逸脱による事故 が増加している.このような事故に対処するには，剛 性の高い防護楖が有効であり, 欧米ではプレキャスト コンクリート製ガードフェンス（以下，PG F と呼ぶ） が広く普及している ${ }^{1)}$,2)。国内においても，高速道 路や自動車専用道路を中心に試験施工が行われており, 基準化等の調査研究活動が進められている. しかしな がら, 未だ明確な基準等は確立されておらず, 普及す るまでには至っていない.

一般に,ガードフェンスには固定型と緩衝型と呼ば れるタイプがあり，海外においてこれらのP G F が用 いられてきた. 固定型とは, 基礎コンクリートと P G $\mathrm{F}$ をアンカーで一体化し, 車両の衝突に対してフェン スの移動を完全に制御するもので，主としてアメリカ で普及している，一方，緩衝型は，ガードフェンスを 基礎上で自由に移動できる構造にしておき，衝突した 車両とともに移動することにより，衝撃力を和らげよ うとするもので, 主としてイタリアで使用されている. 我が国においても, 平成 3 年に実車実験 ${ }^{3)}$ が行われ, いずれの型もガードフェンスとして要求される性能を

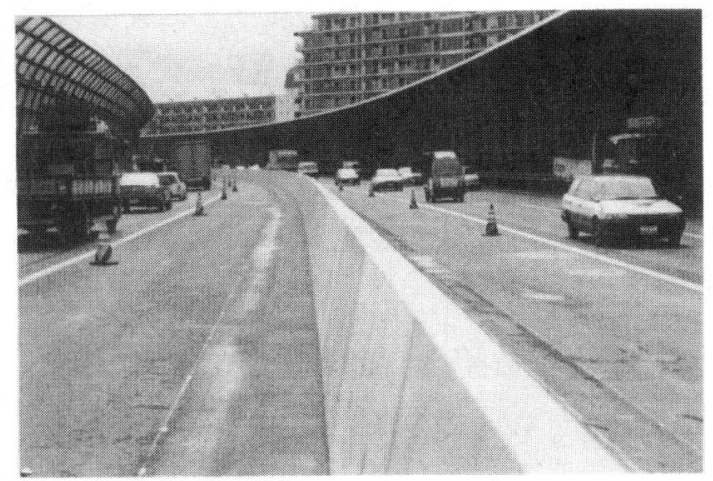

写真-1 土中型 P G F 設置例

十分に満足していることが確認された。しかし，緩衝 型P G F は, 大型貨物車が衝突した場合に最終移動量 がやや大きく, 許容移動余裕幅の小さい中央分離帯で は，移動したP F F が対向車線を侵す可能性があるこ とがわかった。

現在，このような結果を踏まえて，特に基礎等を設 けず，基礎一体型の P G F を土中に埋めこむことによ って, P G F の移動制御と衝撃力の緩和効果を同時に 满足させる土中型 P G F が提案されている.この土中 型P G F は，いくつかのP G F 単体を P C 鋼線で連結 


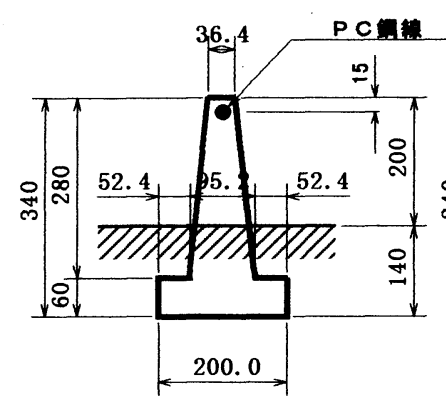

(a) Aタイプ

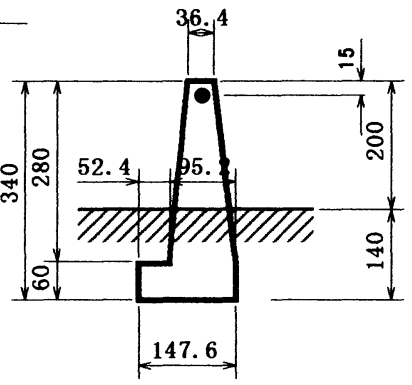

(b) Bタイプ

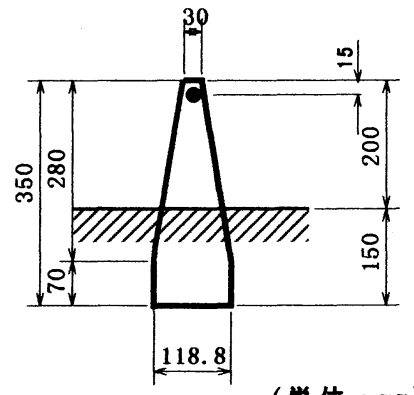

(c) Cタイプ

(単位：mm)

图-1 供試体の形状・寸法
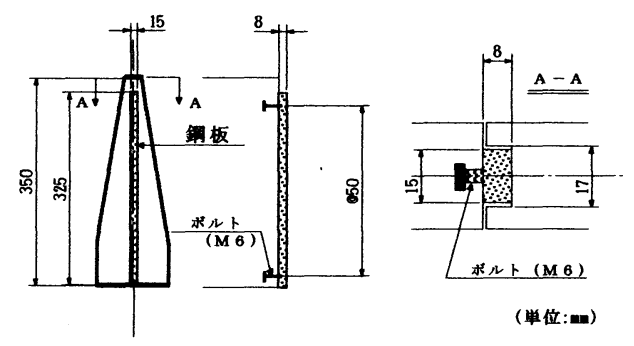

图一2 せん断キーの形状・寸法

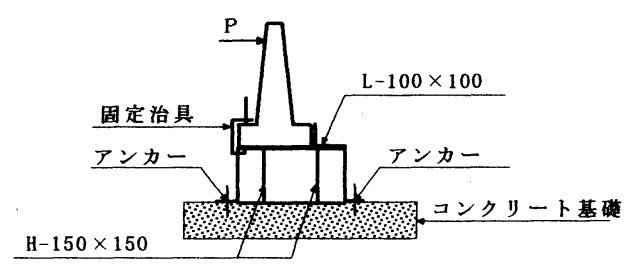

图一3 固定型P G F の概要図
させたもので, 固定型のように基礎コンクリートにボ ルト締めすることもないので, 施工が容易なうえ, さ らに緩衝型に比べ, 移動量も少ないために施工後の維 持補修の経済性という点でも期待されている.この土

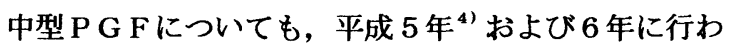
れた害車害験において，そのガードフェンスとしての 性能や安定性が確認されている. しかし, 設計法の提 案等は実験值に依存するところが大きく, 汎用性のあ る解析法については, これからの研究課題とされてい る.

写真一 1 は, 京葉自動車道の重交通量地帯において 設置された土中型P G F の例であり, 高剛性の防護橗 を設置することにより, 車両の衝突による破損や, 対 向車線に逸脱するような重大事故を防止しようとした ものである.

本研究に先立ち, 筆者ら ${ }^{5)}$ は土中型P G F の単体に 関する衝撃模型実験と衝擊応答解析を行い, P G F 単 体の衝撃挙動について基礎的考察を試みた. その結果, P G F 単体の挙動は衝突速度が速くなると平行移動よ りも回転変位が卓越することが認められた. また, 地 盤ばね一質点系を用いた衝撃応答解析により実験結果 を比較的よくシミュレートできることも確認した.

本研究は, 上記の研究結果を踏まえて, さらにP C 鋼線で連結した土中型P G F の衝撃挙動を解明しよう としたものである．まず衝撃模型実験は緩衝効果（モ
デル車両の受ける加速度）と衝撃挙動を明らかにする ために, 連結した土中型P G F を被衝突体とし, 先端 に緩衝性能を模擬した発泡スチロールを取り付け，車 両をモデル化したコンクリート塊を衝突体として, 振 り子式実験装置を用いて行った. 次に, 多質点系の剛 体ばねモデルを用いて, 連結した土中型P G F の衝撃 応答解析を行い, 衝撃を受けた際の P G F の移動量や 車両の受ける加速度を求め, 実験結果と比較検討する ことによりその妥当性を検証した. 最後に, 害際に設 置されたPG Fに対して本法を適用し，本法の応用性 についても検討したものである.

\section{2. 実験の概要}

連結した土中型P G F に車両が衝突した場合, 問題 となるのは次のような項目である.
a) P F Fの変形量
b ）車両の受ける加速度
c) P G F 本体の応力
d）連結用 P C 鋼線の応力

ここでは, 土中型 P G F の形状によって上記の項目が どのように変化するかを実験的に検証し，それらの挙 動を明確にすることを目的として衝揧実験を行った. また同時に静的実験も行い, その荷重〜変位関係も求 めた. 
表一1 コンクリートの配合

\begin{tabular}{|c|c|c|c|c|c|c|c|}
\hline \multirow{2}{*}{$\begin{array}{l}W / C \\
(\%)\end{array}$} & \multirow{2}{*}{$\begin{array}{c}\text { 粗骨材率 } \\
(\%)\end{array}$} & \multicolumn{4}{|c|}{ 単位重量 $\left(\mathrm{kgf} / \mathrm{m}^{3}\right)$} & \multirow{2}{*}{$\begin{array}{c}\text { スランプ } \\
(\mathrm{cm})\end{array}$} & \multirow{2}{*}{$\begin{array}{l}\text { 圧縮強度 } \\
\left(\mathrm{kgf} / \mathrm{cm}^{2}\right)\end{array}$} \\
\hline & & 水 & セメント & 細骨材 & 粗骨材 & & \\
\hline 38.5 & 39.8 & 161 & 419 & 679 & 1059 & 15 & 400 \\
\hline
\end{tabular}

ただし, $1 \mathrm{kgf} / \mathrm{m}^{3}=9.8 \mathrm{~N} / \mathrm{m}^{3}, 1 \mathrm{kgf} / \mathrm{cm}^{2}=0.098 \mathrm{MPa}$

表-2 P C 銅線の機械的性質

\begin{tabular}{|c|c|c|c|c|c|c|c|}
\hline \multirow{2}{*}{$\begin{array}{l}\text { 線径 } \\
(\mathrm{mm})\end{array}$} & \multirow{2}{*}{$\begin{array}{l}\text { 断面積 } \\
\left(\mathrm{mm}^{2}\right)\end{array}$} & \multirow{2}{*}{$\begin{array}{c}\text { 重量 } \\
(\mathrm{kgf} / \mathrm{m})\end{array}$} & \multirow{2}{*}{$\begin{array}{l}\text { 引張強度 } \\
\left(\mathrm{kgf} / \mathrm{mm}^{2}\right)\end{array}$} & \multirow{2}{*}{$\begin{array}{c}\text { 降伏点応力度 } \\
\left(\mathrm{kgf} / \mathrm{mm}^{2}\right)\end{array}$} & \multicolumn{3}{|c|}{ 許容引張応力度 $\quad\left(\mathrm{kgf} / \mathrm{mm}^{2}\right)$} \\
\hline & & & & & $\begin{array}{c}\text { プレストレッ } \\
\text { シング中 }\end{array}$ & $\begin{array}{l}\text { プレストレッ } \\
\text { シング直後 }\end{array}$ & 使用状態 \\
\hline$\phi 5$ & 19. 64 & 0.154 & $165(3250)$ & $145(2850)$ & $131(2565)$ & $116(2275)$ & $99(1950)$ \\
\hline
\end{tabular}

（ ）内の数字はそれぞれの荷重 $(\mathrm{kgf})$ を示す. ただし, $1 \mathrm{kgf}=9.8 \mathrm{~N}, 1 \mathrm{kgf} / \mathrm{mm}^{2}=9.8 \mathrm{MPa}$

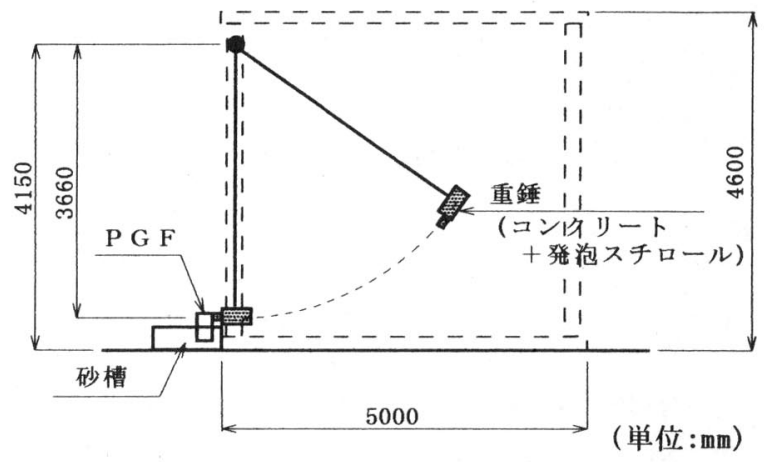

図-4 振り子式実験装置

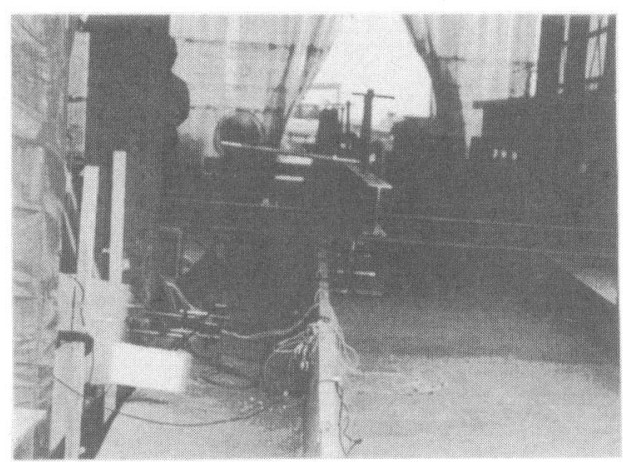

写真-2 衝擊模型実験概要

\section{（1）供試体}

供試体形状は，図一 1 に示すような土中型 P G F と して現在提案されている 3 タイプを使用した。 寸なわ ち，両側にフーチングを有するAタイプ，片側のみに フーチングを有するBタイプ，およびフーチングのな い単スロープ型と呼ばれているCタイプである．奥行 きについてはすべて $1.0 \mathrm{~m} ゙$ ある。 また，供試体寸法は 実物の $1 / 5$ のスケールとしたため, 重量は実物の $1 / 5^{3}$ となっており，それぞれAタイプは84.2kgf，Bタイ

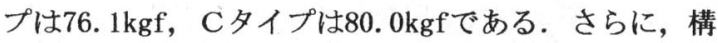
造的には実物の鉄筋量の $1 / 5$ 程度を配筋した R C 構造 とし，コンクリートの設計基準強度は実物と同じ $400 \mathrm{k}$ $\mathrm{gf} / \mathrm{cm}^{2}$ とした. 用いたコンクリートの配合を表ー 1 に 示す.

各供試体の接合部は, 図一 2 に示すようにせん断キ 一と呼ばれる凹凸でかみ合う構造となっている，せん 断キーは実物においては，鉄筋コンクリート構造とな っているが，模型ではその寸法が小さいために鋼板を 用いるものとした. 実験用P G F は，これらの供試体 を19個並べた後に, 天端から $15 \mathrm{~mm}$ の位置に配置した $\mathrm{P}$ C鋼線を緊張することにより連結構造とした. ここで, 実物の P G F ではP C 鋼棒はSBPR930/1080, $=26 \mathrm{~mm}$

$\left(\right.$ 断面積 $530.9 \mathrm{~mm}^{2}$ ) を用いて初期緊張力として $25 \mathrm{tf}$ （降伏点荷重50.4tfの1/2）を導入しているので, 模 型にお゙いては，P C鋼線をSWPR1, =5mm（断面積 19.63 $\left.\mathrm{mm}^{2} \fallingdotseq 530.9 \times\left(1 / 5^{2}\right)\right)$ とし, 初期緊張力を $1.5 \mathrm{tf}$ (降 伏点荷重2. $85 \mathrm{tf} \times 1 / 2)$ とした. 表一 2 に実験に用い た P C 鋼線の機械的性質を示す.また，図一ろのよう にAタイプのフーチングを固定することによって, 固 定型P G F の実験も行うものとした.

\section{（2）実験装置}

一般に, 車両による P G F 几の衝突は車線方向に対 し $20^{\circ}$ の角度の斜め衝突とされているが，ここでは斜 め衝突のうち, P G F 側にとって最も危険となる垂直 成分のエネルギーのみを考虑した振り子式衝突実験を 行うこととした。すなわち，振り子式実験装置を用い た衝撃模型実験の概要を図ー4および写真一2に示す. 重鍾は総重量 $20 \mathrm{tf}$ の大型貨物車両を $1 / 5$ の縮尺でモデ ル化するものとした. 寸なわち, 重量は $160 \mathrm{kgf}(=20.0$ $\left.\mathrm{tf} / 5^{3}\right)$ のコンクリート塊で模擬し，バンパー等のク ッション性能は, 先端に発泡スチロールを付けること で模擬するものとした. 衝突速度は衝突車両の運動エ ネルギーがすべて P G F の剛体運動による吸収エネル ギーに変換されるものとして, 次の相似則を用いて算 出するものとした ${ }^{6) ， 7) . ~}$ 


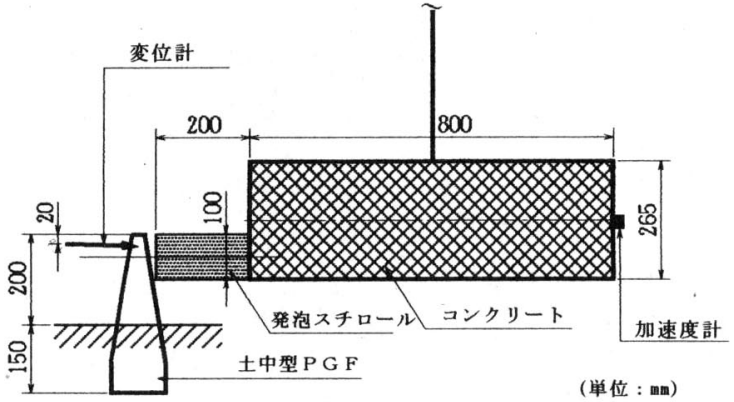

(単位：mm)

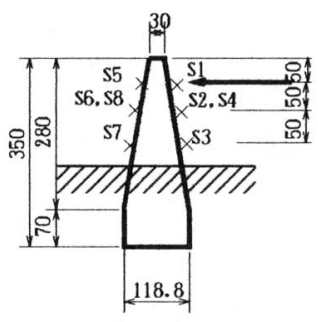

(b) P G Fひずみゲージ位置

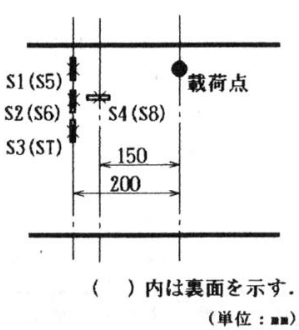

(単位 : m m)

（a）測定概要図（側面図）

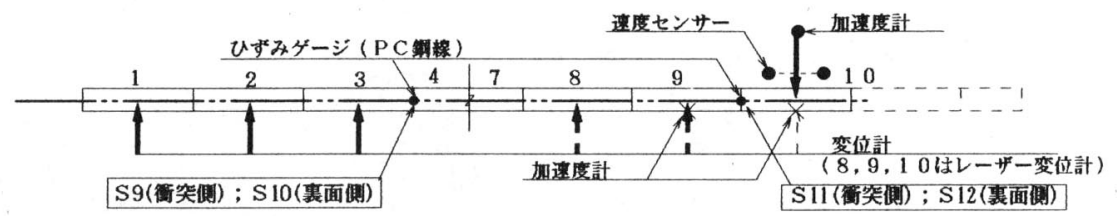

（c）測定概要図（平面図）

図-5 測定項目概要図

$$
\frac{V^{\prime}}{V}=\sqrt{\frac{l^{\prime}}{l}}
$$

ここに, $V^{\prime}$ : 実物車両速度

$\mathrm{V}$ : モデル車両速度

$\ell^{\prime}$ : 実物 P G F 長さ

$\ell:$ モデルPGF長さ

よって, 実物車両の衝突条件を, 衝突速度 $100 \mathrm{~km} / \mathrm{h}$, P G F への進入角度 $20^{\circ}$ とすると, モデル車両の P G $\mathrm{F}$ 垂直方向速度成分は次のようになる.

$\mathrm{V}=\frac{100000}{3600} \times \sin 20^{\circ} \times \frac{1}{\sqrt{5}}=4.1 \mathrm{~m} / \mathrm{sec} \fallingdotseq 4.0 \mathrm{~m} / \mathrm{sec}$

また,この時の振り子の振り上げ高さは0. $816 \mathrm{~m}\left(=\mathrm{V}^{2} /\right.$ $\left.(2 \times \mathrm{g})=4.0^{2} /(2 \times 9.8)\right)$ とし, 重鍾の衝突中心位置は P GFの上端から $5 \mathrm{~cm}$ とした.

なお，土としてはコンクリート用細骨材（砕砂）を 使用し, 毎回実験後に一旦除去してP G F 設置時に振 動プレートを用いて締め固めるものとした. ところで, 実際の P G F を中央分離帯に設置する場合, 路盤工を 切削LPG F を設置した後に, 埋め戻し土を機械によ って転圧するか, 舖装を敷設するので地盤の強度は実 験時よりも大きくなる. 例えば，実験時の平板載荷試 験による鉛直方向地盤反力係数は $4.2 \mathrm{kgf} / \mathrm{cm}^{3}$ 程度であ り, 実際の締まった砂質土の值に対して半分程度の值 を示している. しかし, 本実験においては変位量を大 きく表し, 土の影響を顕著にするために, 均一な材料
を用いて比較的柔らかい土による実験を行うものとし た.

測定項目は，図一5に示寸とおりである.すなわち， モデル車両側は速度センサー（キーエンス・FS-L50）による 衝突速度と, 加速度計 (容量200G) による加速度を測 定した. また，PG F 側は加速度計（容量200G）によ る加速度, レーザー変位計 (測定範囲 $\pm 100 \mathrm{~mm}$ ) と作 動トランス式変位計（容量 $50 \mathrm{~mm}$ ) による天端変位とひ ずみゲージ（グージ長 $60 \mathrm{~mm}, 3 \mathrm{~mm}$ ) による P G Fおよ びP C龬線のひずみとした，各データは，動ひずみ計 とAD変換ボードを介して測定した.

また，静的実験は 19 個並べた P G F の中央部（10 番目）を油圧ジャッキで押し，ロードセル（容量2tf） による荷重と各P G F の天端変位を, 静的ひずみ測定 器を用いて測定するものとした。

\section{(3) 実験ケース}

実験は, 表一3に示すように土中型の 3 タイプの供 試体に対して静的および衝揧実験を行い, 固定式PG Fについては衝撃実験のみを行った. なお, 衝撃実験 は結果のばらつきを考慮し，2回ずつ行うものとした。

\section{3. 実験結果および考察}

\section{（1）静的実験における荷重～変位関係}

図一 6 は, 静的実験における載荷点位置の荷重〜変 


\begin{tabular}{|c|c|c|}
\hline $\begin{array}{c}\text { ケース } \\
\text { No. }\end{array}$ & $\begin{array}{c}\text { P G F } \\
\text { タイプ }\end{array}$ & $\begin{array}{c}\text { 衝突速度 } \\
\text { V (m/sec })\end{array}$ \\
\hline 1 & 固 定 & 4.0 \\
\hline 2 & A & 静 的 \\
\hline 3 & A & 4.0 \\
\hline 4 & B & 静 的 \\
\hline 5 & B & 4.0 \\
\hline 6 & C & 静 的 \\
\hline 7 & C & 4.0 \\
\hline
\end{tabular}

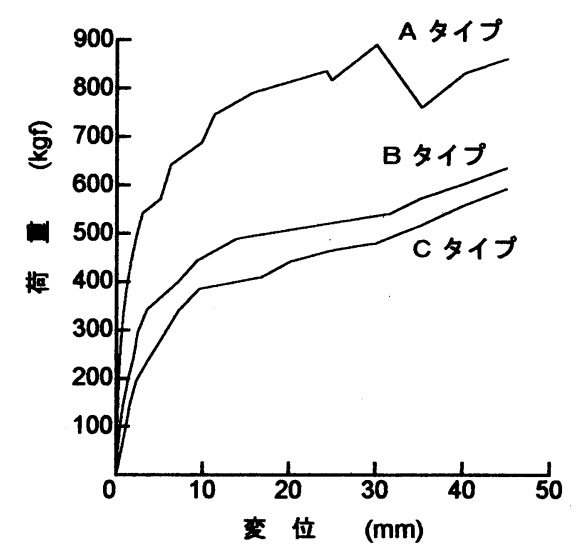

图-6 静的載荷時の載荷点における 荷重～変位関係 $\quad(1 \mathrm{kgf}=9.8 \mathrm{~N})$

位関係である. 単体実験 ${ }^{5)}$ においては軟化型の弾塑性 傾向を示していたが, 図より，P C鋼線によって連結 されたP F F は，各タイプとも硬化型の弾塑性挙動を 示していることがわかる.これは, 連結された 19 個 のP G Fが, 背面や衝突側の土が降伏した後も, 全体 で抵抗しているためと考えられる。 また，Aタイプは BタイプやCタイプに比べて, 同一変位において約 1. 5 倍の荷重が得られた.これは, 衝突側および裏 面側のフーチング上の土の重量の効果によって, 転倒 に対する抵抗モーメントが大きくなったためと思われ る. 图一 7は, 载荷点 P G F の変位が45mに達したと きの各PGFの変位分布を示したものである.これよ り， A， B，Cのいずれのタイプにおいても中心の 5 個のP G F の変位が突出しており, Na.10の変位はN No.7 の変位の約 6 倍に達していることが読みとれる.つま り, この部分のP G F に荷重が集中して作用している ことがわかる. ただし今回の実験においては, 連結用 $\mathrm{P} \mathrm{C}$ 鋼線に1.5tfの緊張力を与えることによって各 $\mathrm{P}$ G F を一体化させているために，このような変位分布 となった. しかし，例えばこの緊張力の大きさを増加 させると, 全体の剛性も増大するので, この変位分布

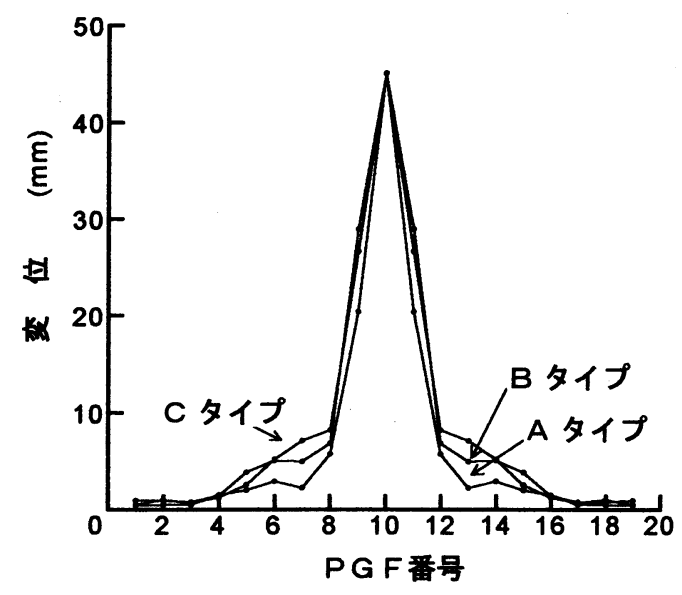

图一7 静的載荷時の変位図

も小さくなるものと思われる.これについては別途定 量的検討を行う予定である.

\section{（2）復突時のP G F 本体およびP C鋼線のひずみ}

图一8に, 実験ケース№.3における衝突点P G F 本 体に生じたひずタ〜時間関係を示す。この図より衝突 直後にP G F の衝突面側では, 車線方向に直角に貼つ たゲージ（S1, S2, S3）には当初引張応力が生じており， 平行に貼ったゲージ（S4）には圧縮応力が生じている ことがわかる. また, 裏面側では逆の応力分布を示し ている.つまり衝突点のP G F は, 鉛直方向には土中 部を固定端とした片持ち梁のような曲げ変形を生じて おり, 一方, 車線方向には連結部を支点とした梁のよ うな曲げ変形を生じているものと思われる. しかし, 最大ひずみは約70ゃであり，コンクリートのひび割れ 限界値の 200 以下であるため, クラックは生じていな い. すなわち, 車両の衝突に対してPGFは, ひび割 れや破壊を起こすことなく，ほぼ弾性挙動を示してい ると言える. なお, 図一8 (a)の残留ひずみがS1, S2, S 3において圧縮の值を示し, S4において引張の値を示 している.これは, 重鍾の衝突によってアンボンド状 態のP C 鋼棒の位置がシース内で移動したために, プ レストレスによる応力状態が初期条件と変化したため と思われる.

图一9に，実験ケース№.3における P C 鋼線に生じ たひずみ〜時間関係を示す。これより, 衝突点より離 れた点（S9, S10）では一様に引張応力が働くが, 衝突 点近傍 $(\mathrm{S} 11, \mathrm{~S} 12)$ では衝突時 $(100 \mathrm{msec}$ 後) にひずみ がほぼ対称となっているので, 曲げひずみが作用して いることがわかる. しかし，その最大値は 1200 程度 で, P C 銅線の破断ひずみ（8250»）よりはるかに小 さく安全であることがわかる.

これらの傾向はすべての実験ケースにおいて認めら 


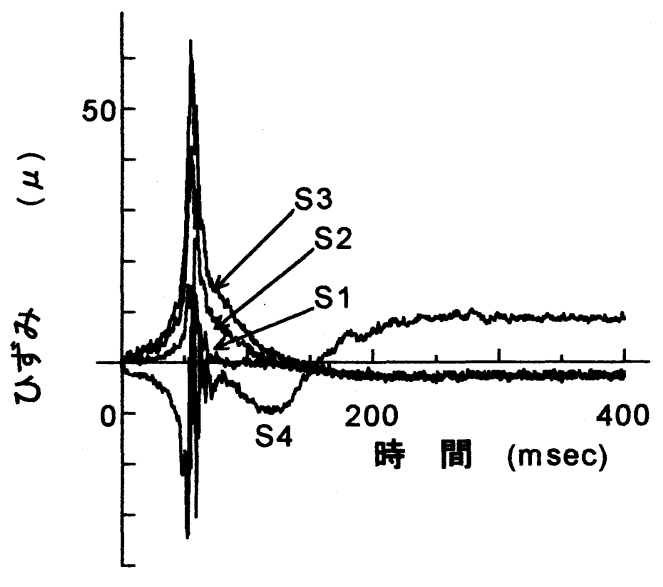

(a) 衝突面

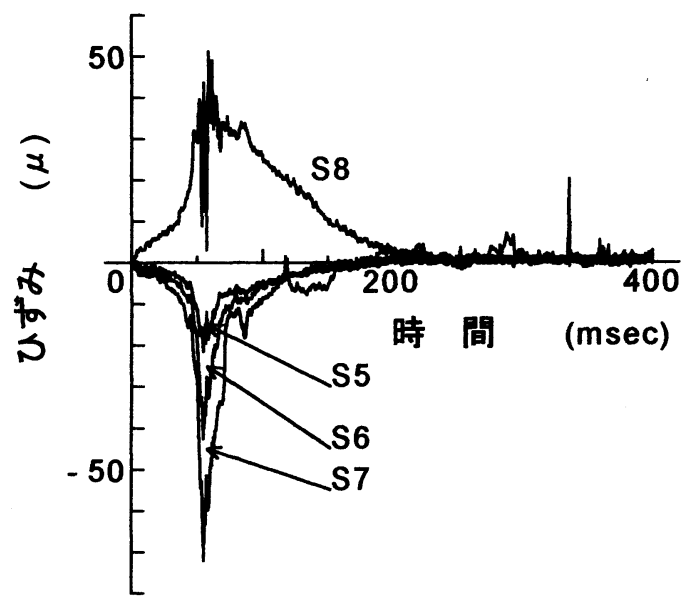

(b) 背 面

图ー8 PGFのひずみ〜時間関係

(Aタイプ, V=4.0m/sec)

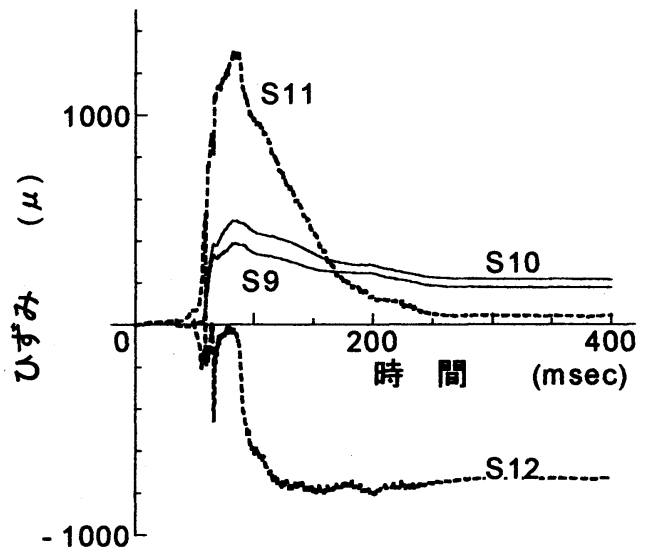

图ー9P P 鋼線のひずみ〜時間関係

(Aタイプ, $4.0 \mathrm{~m} / \mathrm{sec})$

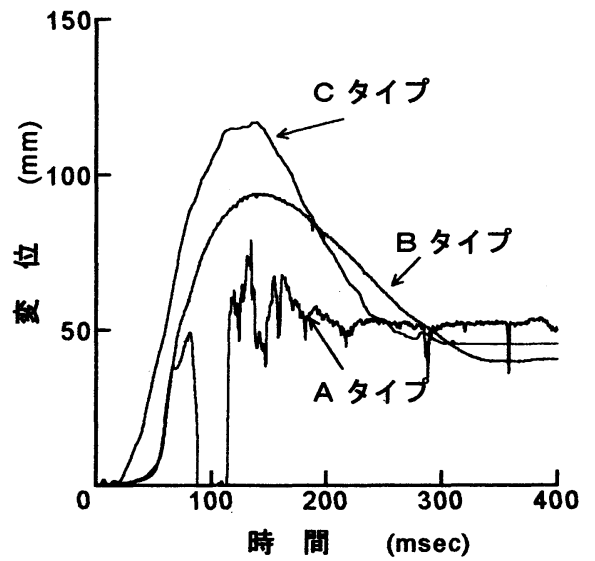

图一 10 衝突点P GF の変位〜時間関係
れ，P C鋼線については破断等が生じないことが確認 された.

\section{（3）変位 時間関係}

图一 10 ○衝突点のP G F の変位〜時間関係を示す. これより, P G Fの最大変位は C, B, Aタイプの順 に大きくなっていることがわかる．また，残留変位は $\mathrm{A}, \mathrm{C}, \mathrm{B}$ タイプの順に大きくなっているが，その大 きさは40〜 50mm程度である.ここで, 実験で得られた 残留変位は, 主にP G F の水平移動量を表しているも のと考えられる.これは土の抵抗力によって決定され る值であり, 今回の実験においては各供試体の土中へ の埋め込み深さが一定であったために，大きな差が生 じなかったものと思われる. また，最大変位と残留変 位の差は主に P G F の回転変位の戻り量と考えられる が，実験において回転変位を测定しなかったために定
量的に評価することは困難である. しかし，定性的に はビデオによる観察から AタイプのP G F の回転変位 が小さく, Cタイプの回転変位が大きいことが確認さ れた. また, 形状からもこのような特性が推測される が, 定量的な判断は今後の研究課題とする.

\section{(4) PGF変位分布}

图一 11 に各タイプの最大および残留変位分布を示 す。これより, Cタイプが最も衝突点の最大変位が大 きく現れていることがわかる. また, 各タイプの形状 の相異にかかわらず, 全範囲にわたって残留変位が最 大変位よりも減少しているが, 衝突点の戻り量はA, B, Cタイプの順に小さくなっている. さらに, 各夕 イプとも中央部の $5 つ(\mathrm{Na} 8,9,10,11,12)$ にP F F 変位が集中していることも認められる. 表一 4 にC タ イプのP G F の各変位と, 変位の総和で P. G F の各変 


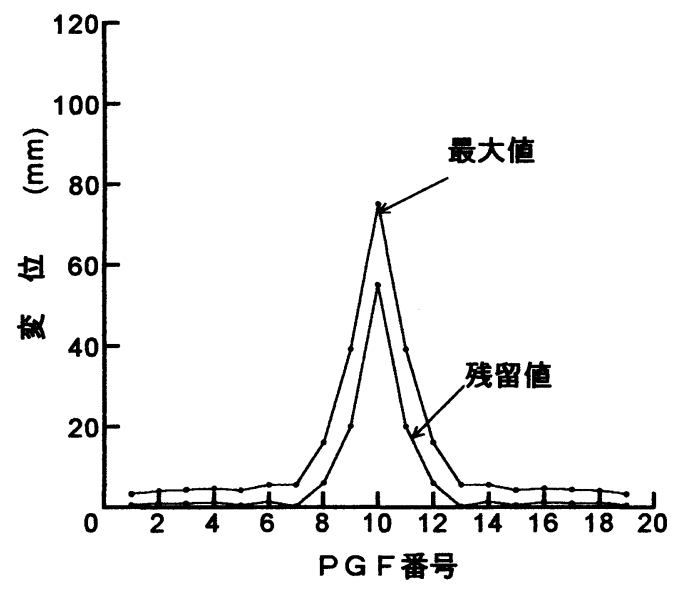

(a) Aタイプ

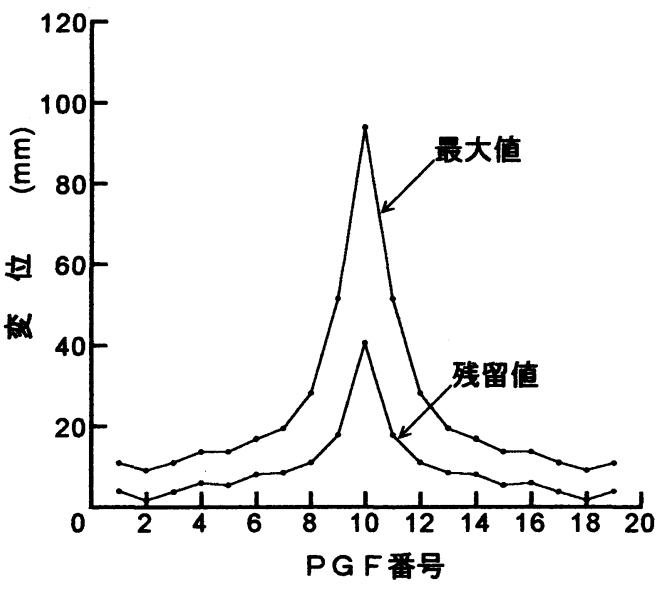

(b) Bタイプ

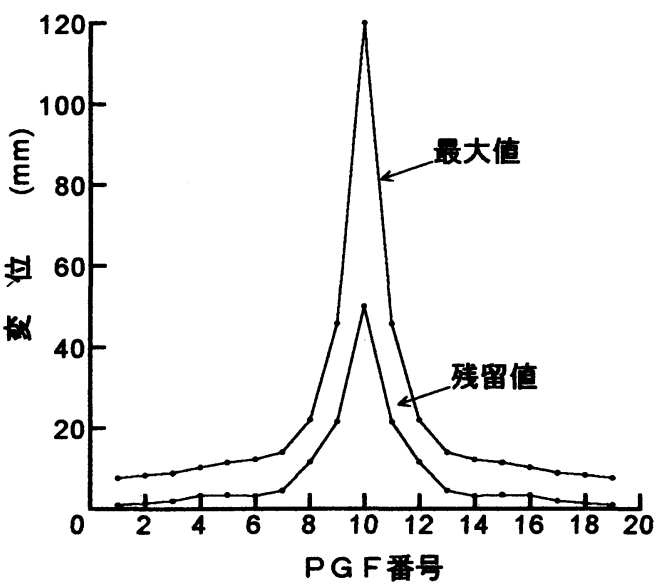

(c) Cタイプ

图-11 P G F の変位分布図
埊－4 P GFの変位一覧表（Cタイプ）

\begin{tabular}{|c|c|c|c|c|}
\hline PGF & 最大変位 & $\begin{array}{c}\text { 変 位 } \\
\text { 分配率 } \\
(\%)\end{array}$ & 残留変位 & $\begin{array}{c}\text { 変 位 } \\
\text { 分配率 } \\
(\%)\end{array}$ \\
\hline 1 & 7.6 & 1.9 & 1.0 & 0.7 \\
\hline 2 & 8.3 & 2.1 & 1.4 & 0.9 \\
\hline 3 & 8.8 & 2.2 & 2.0 & 1.3 \\
\hline 4 & 10.2 & 2.6 & 3.3 & 2.2 \\
\hline 5 & 11.5 & 2.9 & 3.4 & 2.2 \\
\hline 6 & 12.2 & 3.0 & 3.1 & 2.0 \\
\hline 7 & 13.9 & 3.5 & 4.4 & 2.9 \\
\hline 8 & 21.9 & 5.5 & 11.5 & 7.5 \\
\hline 9 & 45.7 & 11.4 & 21.5 & 14.0 \\
\hline 10 & 120.0 & 29.9 & 50.0 & 32.6 \\
\hline
\end{tabular}

位を除した值（変位分配率と呼ぶ）を示す.この表か らも中央の 5 つの P G F (No. 8〜 12)において変位が集 中していることがわかる.この傾向は $\mathrm{A}, \mathrm{B}$ タイプに ついても同様であった. したがって, 今回の実験結果 からは，P C鎆線で連結されたP F Fに車両が垂直に 衝突した場合, その衝撃力は衝突点を中心とする 5 つ のPG Fで分担されることがわかる.ただし，今回の 実験において, 衝突時に衝突点近傍の接合部において せん断キーの凹部が破壊し, 十分なせん断力の伝達が なされていなかったために, 実際のP G F の挙動とは 異なっているものと思われる. また，P C 鋼線の緊張 力や土中への根入れ深さ等も, 変位分布を決定する大 きな要因になると思われるが，これらの影響について は, 今後の検討課題とする.

\section{（5）突車両の加速度}

图一 12 に衝突車両の加速度〜時間関係（A，B夕 イプは 2 回目，Cタイプは1回目）を示す．また表一 5 に最大加速度を示す. 実験は各タイプにつき 2 回ず つ行った結果, 一部の実験では振り子の衝㔖後に発泡 スチロールが局部的に破損した例があったが, 最大加 速度までの加速度〜時間関係はほぼ同じ傾向を示した. また, 最大加速度については土の締め固め条件の相違 等から，1回目と 2 回目でばらつきが見られるが，こ こでは平均値について検討を行うものとした.これよ り，土中型P G F に衝突した車両の衝撃力は, 固定型 の4〜5割程度に低減されていることがわかる.また， 土中型 P G F を比較した場合，A，Bタイプはあまり 差がないが, Cタイプの加速度が Aタイプよりも約 30 程度低減されていることが認められる.これは，C タイプの回転変位が大きいために, 車両の衝撃力が低 減されたためと思われる. 


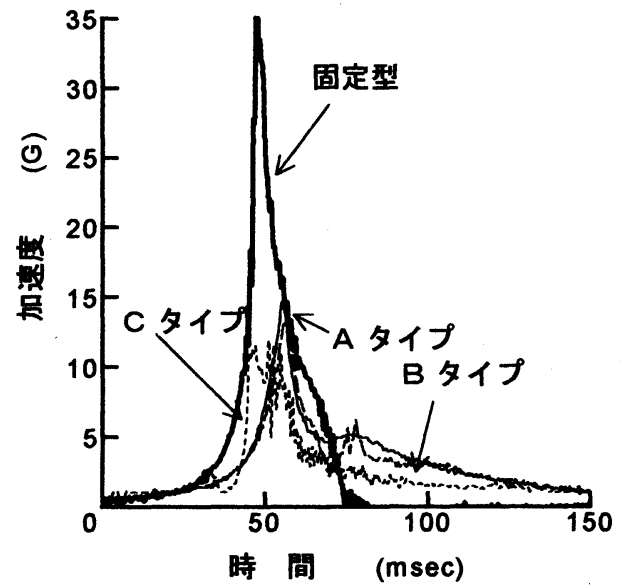

図-12 車両の加速度〜時間関係

衰一 5 車両の最大加速度一覧表 (単位; $\mathrm{G}$ )

\begin{tabular}{|c|c|c|c|}
\hline 供試体タイプ & 1回目 & 2回目 & 平 均 \\
\hline 固定型 & 27.0 & 37.0 & 32.0 \\
& $(1.0)$ & $(1.0)$ & $(1.0)$ \\
\hline $\mathrm{A}$ & 16.5 & 14.0 & 15.3 \\
& $(0.61)$ & $(0.38)$ & $(0.48)$ \\
\hline $\mathrm{B}$ & 16.0 & 13.7 & 14.9 \\
& $(0.59)$ & $(0.37)$ & $(0.47)$ \\
\hline $\mathrm{C}$ & 12.0 & -- & 12.0 \\
& $(0.44)$ & & $(0.38)$ \\
\hline
\end{tabular}

（）内の值は固定型との比率を表す

\section{4. 解析の概要}

土中型 P G F は, 移動制御や施工性という観点から, 固定型および緩衝型P G F に比べ優れている. また, 前述の実験結果からは, 両側にフーチングを有する A タイプが最大移動量の制御に効果があることや，車両 の受ける加速度の低減にはCタイプが効果的であるこ とが確認された。

さて, 実験結果より P G F 本体や連結用 P C 銅線が 破壊に対して十分安全であり，P F F 本体は剛体と，し て挙動していると判断することができた. よって,こ こでは, 連結P G F を剛体ばねにモデル化したうえで, 背面の土を考虑に入れた衝撃応答解析法の開発を試み, 衝突時の最大変位の分布や車両の受ける加速度を算定 する. また, この衝撃応答解析結果を実験結果と比較 することにより, 本解析法の妥当性を検証し, さらに, この解析法を用いて実際に設置されたP F F 衝撃挙 動のシミュレーションを行った. また最後に, 本解析 法の問題点と今後の課題についても若干の考察を加え るものである.

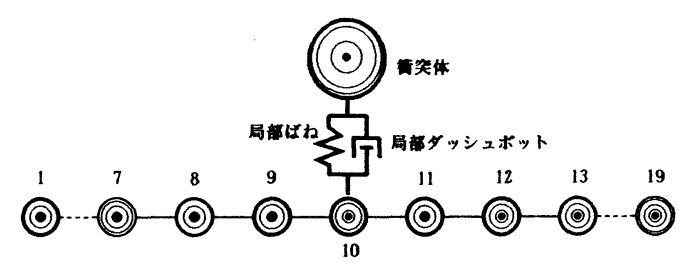

(a)離散化モデル

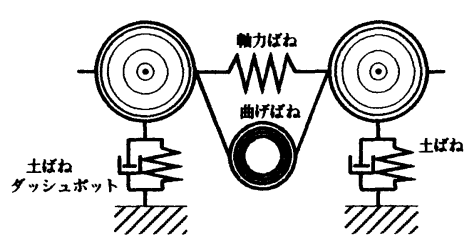

(b) 㣚体ばね要素

図一13 解析モデル

\section{（1）解析モデル}

解析モデルは，図ー1 3 に示すように 1 個の P G F を 1 質点と想定し， 19 個のP G F をそれぞれの質点 間に軸力ばねと曲げばねを有する剛体質点の離散化モ デル ${ }^{8)}$ に置換し, 車両と P G F 間は局部ばねと局部ダ ッシュポットで置き換えるものとした. なお, 各 P G $\mathrm{F}$ 間のせん断力については, 質点間において完全に伝 達されるものとして解析を行った. また, 各P F Fの 背面には, 图一 13 (b)のように土をモデル化した圧 縮方向のみに働く土ばねおよび土のダッシュポットを 設けた.

\section{（2）解析の基本式}

図一 13 のようにモデル化したP G Fに対する基本 式は, 图一14の変形図を参照にしてi質点を例にと ると以下のように導かれる.ここで，隣接した質点の 重心位置を結んだ軸線方向を法線方向と呼ぶ. まず, 微小時間 $\Delta t$ における $\mathrm{i}-\mathrm{j}$ 質点間の法線方向相対変位 は, 次のように表される.

$$
\begin{aligned}
& \Delta \mathrm{u}_{n \mathrm{i}}=\left(\Delta \mathrm{x}_{\mathrm{i}}-\Delta \mathrm{x}_{\mathrm{j}}\right) \cos \beta_{\mathrm{ij}}+\left(\Delta \mathrm{y}_{\mathrm{i}}-\Delta \mathrm{y}_{\mathrm{j}}\right) \sin \beta_{\mathrm{ij}} \\
& こ こ に, \quad \beta_{\mathrm{ij}}=\tan ^{-1}\left\{\frac{\mathrm{y}_{\mathrm{j}}-\mathrm{y}_{\mathrm{i}}}{\mathrm{x}_{\mathrm{j}}-\mathrm{x}_{\mathrm{i}}}\right\}
\end{aligned}
$$

ただし, $\Delta \mathrm{u}_{\mathrm{n} i \mathrm{i}}$ : 微小時間 $\Delta \mathrm{t}$ における $\mathrm{i}-\mathrm{j}$ 質点間法線方 向相対変位, $\beta_{11}$ : 時刻 $\mathrm{t}$ $\mathrm{i}$ 質点と $\mathrm{j}$ 質点との相対回転 角, $x_{i}, y_{i}$ 時刻 $\mathrm{t}$ 質点の $\mathrm{x}$ 座標, $\mathrm{y}$ 座標, $x_{i}, y_{1}$ : 時 刻 $\mathrm{t}$ 質点の $\mathrm{x}$ 座標, $\mathrm{y}$ 座標, $\Delta \mathrm{x}_{\mathrm{i}}, \Delta \mathrm{y}_{\mathrm{i}}: \mathrm{i}$ 質点の $\mathrm{x}$ 座標, $y$ 座標の前時間加ら座標変化量, $\Delta x_{1}, \Delta y_{j}$ : $\mathrm{j}$ 質点の $\mathrm{x}$ 座標, $\mathrm{y}$ 座標の前時間からの座標変化量.

また, i質点の回転角は図-14(c)を参照に次の式 


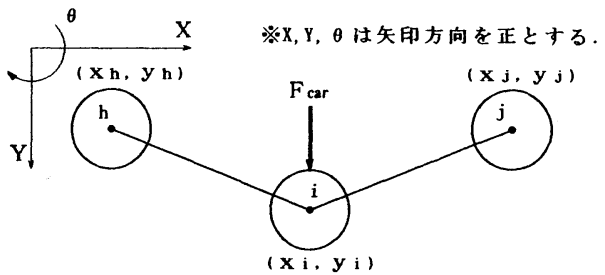

(a) P G F の変形図

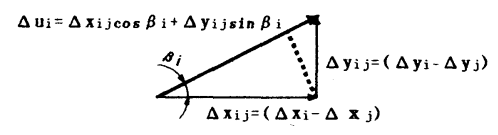

（b）法線(舳線) 方向の相对変位の算出方法

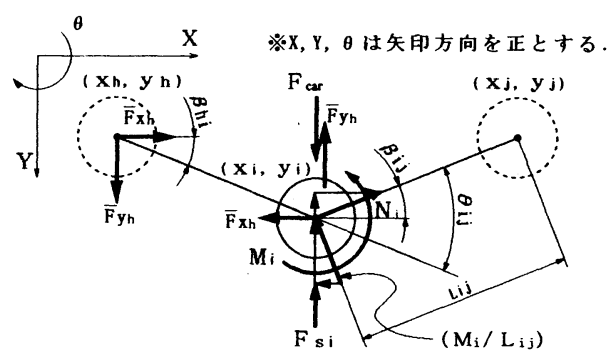

(c) i 質点の回転角とカのつり合い図

图-14 PGFの変形と力のつり合い図

によって算出される.

$$
\theta_{i j}=-\beta_{h i}+\beta_{i j}=-\tan ^{-1}\left\{\frac{y_{i}-y_{h}}{x_{i}-x_{h}}\right\}+\tan ^{-1}\left\{\frac{y_{j}-y_{i}}{x_{j}-x_{i}}\right\}
$$

ただし, $\theta_{i \mathrm{i}}$ : i質点の回転角, $\beta_{\mathrm{hi}}$ : 時刻 $\mathrm{t} の \mathrm{~h}$ 質点と $\mathrm{i}$ 質点との相対回転角, $\mathrm{x}_{\mathrm{h}}, \mathrm{y}_{\mathrm{h}}$ : 時刻 $\mathrm{t}$ $\mathrm{h}$ 質点の $\mathrm{x}$ 座標, $\mathrm{y}$ 座標.

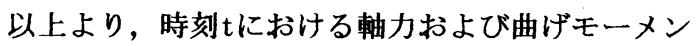
トは次式より算出できる.

$$
\begin{aligned}
& N_{i}=N_{i}(t-\Delta t)+K_{n} \cdot \Delta U_{n i} \\
& M_{i}=K_{m} \cdot \theta_{i j}
\end{aligned}
$$

ただし， $N_{i}, M_{i}$ : i 質点に作用する軸力および曲げモー メント, $N_{i}(t-\Delta t)$ : 前時間に $i$ 質点に作用していた軸力, $\mathrm{K}_{\mathrm{n}}, \mathrm{K}_{\mathrm{m}}$ : 軸力および曲げばね定数.

次に，i質点に作用する軸力および曲げモーメント を用いて，i質点の $\mathrm{x}, \mathrm{y}$ 座標方向の作用力がそれぞ れ次式のように算定される.

$$
\begin{aligned}
& \mathrm{Fx}_{\mathrm{i}}=-\mathrm{N}_{\mathrm{i}} \cos \beta_{i \mathrm{j}} \\
& \mathrm{Fy}_{\mathrm{i}}=-\mathrm{N}_{\mathrm{i}} \sin \beta_{\mathrm{i}}+\left(\mathrm{M}_{\mathrm{i}} / \mathrm{L}_{\mathrm{i}}\right) \cos \beta_{i},
\end{aligned}
$$

ただし， $\mathrm{Fx}_{\mathrm{i}}, \mathrm{Fy}_{\mathrm{i}}$ : i質点に作用する $\mathrm{x}$ 方向および $\mathrm{y}$ 方 向の合力, $L_{i j}: i j$ 質点間の距離.

さらに，背面土による作用力と $\mathrm{h}$ 質点に作用する反 力を加算することにより, $\mathrm{i}$ 質点の時刻 $\mathrm{t}$ たおける総作 用力を算出することができる.

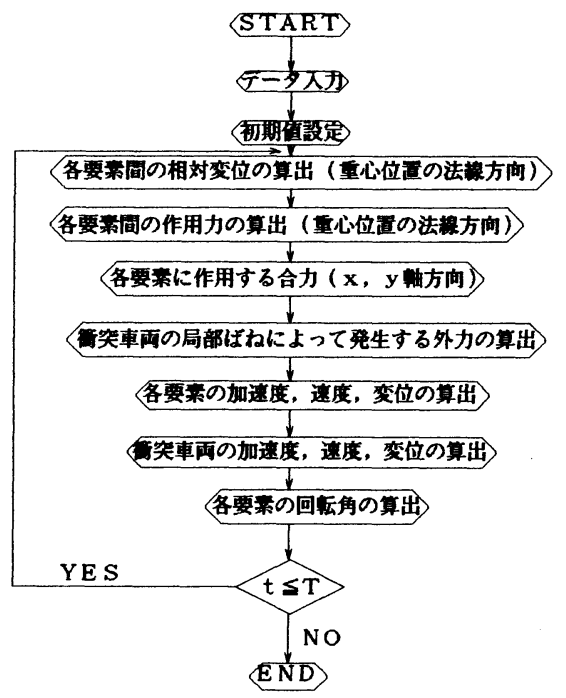

图-15 解析フローチャート

$$
\begin{aligned}
& \vec{F} x_{\mathbf{x}_{i}}=F x_{x_{i}}+\left(-\bar{F} x_{h}\right) \\
& \vec{F} y_{i}=F y_{i}+\left(-\bar{F} y_{h}\right)-F s_{i}
\end{aligned}
$$

ここに, $\quad \mathrm{Fs}_{\mathrm{i}}=\mathrm{C}_{\mathrm{s}} \cdot \dot{\mathrm{u}}_{\mathrm{i}}+\mathrm{K}_{\mathrm{s}} \cdot \mathrm{y}_{\mathrm{i}}$

ただし， $\bar{F}_{\mathbf{x}_{i}}, \overline{\mathrm{F}} \mathbf{y}_{\mathbf{i}}$ : i質点に作用する $\mathrm{x}$ 方向および $\mathrm{y}$ 方 向の総作用力, $F s_{\mathrm{i}}$ : i質点に作用する背面土による作 用力, $\bar{F}_{x_{h}}, \bar{F} y_{h}: h$ 質点に作用する $x$ 方向および $y$ 方向 の総作用力, $\mathrm{K}_{\mathrm{s}}, \mathrm{C}_{\mathrm{s}}$ : 背面土のばね定数および堿衰係数, $\dot{\mathrm{u}}_{\mathrm{i}}: \mathrm{i}$ 質点の変位速度.

一方，時刻 $\mathrm{t}$ において車両に作用寸る衝擊力は次の 式を用いて算出することができる.

$$
\begin{aligned}
& \mathrm{F}_{\mathrm{car}}=\mathrm{C}_{\mathrm{car}} \cdot \dot{\mathrm{U}}_{\mathrm{cp}}+\mathrm{K}_{\mathrm{car}} \cdot \mathrm{u}_{\mathrm{cp}} \\
& \text { ここに, } \quad \dot{\mathrm{U}}_{\mathrm{c} \mathrm{p}}=\dot{\mathrm{u}}_{\mathrm{cAr}}-\dot{\mathrm{u}}_{\mathrm{n} \mathrm{p}}, \mathrm{u}_{\mathrm{c} \mathrm{p}}=\mathrm{u}_{\mathrm{c} a \mathrm{r}}-\mathrm{u}_{\mathrm{n}} \mathrm{p}
\end{aligned}
$$

ただし, $\mathrm{F}_{\mathrm{car}}$ : 車両に発生する衝撃力, $\mathrm{K}_{\mathrm{car}}, \mathrm{C}_{\mathrm{car}}$ : 車 両の局部ばねおよび減衰係数, $\mathrm{u}_{\mathrm{CD}}, \dot{\mathrm{U}}_{\mathrm{C} D}$ : 車両の相対変 位および相対速度, $\mathrm{U}_{\mathrm{c}} \mathrm{r}_{\mathrm{r}}, \dot{U}_{\mathrm{c}} \mathrm{r}$ : 車両の変位および速度, $u_{n p}, \dot{u}_{n p}$ : 衝突点P G F の y 方向変位および速度.

よって, 衝突点での総作用力は式 (10)の衝突点 P G Fの力と式(12)を加え, 次のようになる.

$$
\mathrm{F}_{\mathrm{np}}=\overline{\mathrm{F}}_{\mathrm{np}}+\mathrm{F}_{\mathrm{car}}
$$

ただし, $F_{n p}$ : 衝突点P G F の y 軸方向総作用力, $\bar{F}_{n p}$ : 式(10)の $\mathrm{i}=\mathrm{np}$ とした $\mathrm{y}$ 軸方向の作用力, $\mathrm{np}$ : 衝突点 P G F 番号.

以上の計算によって, 時刻 $\mathrm{t}$ における各質点の作用 力が算出される. したがって, 時刻 $\mathrm{t}+\Delta \mathrm{t}$ における車 両および各質点の加速度, 速度および移動量はオイラ 一法" に基づき次の式によって求められることになる.

$$
\ddot{U} x_{i}=\frac{\bar{F} x_{i}}{m_{i}}, \quad \ddot{U} y_{i}=\frac{\bar{F} y_{i}}{m_{i}}, \quad \ddot{U}_{c a r}=\frac{F_{c a r}}{m_{c a r}}
$$




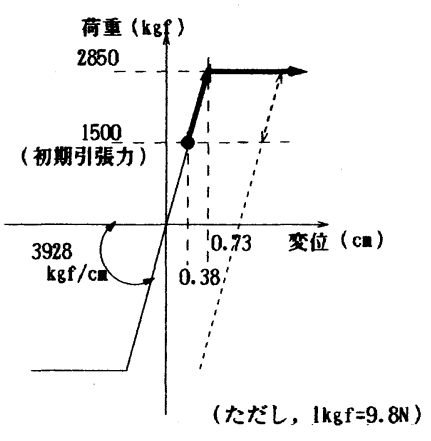

図ー16 軸力ばねモデル

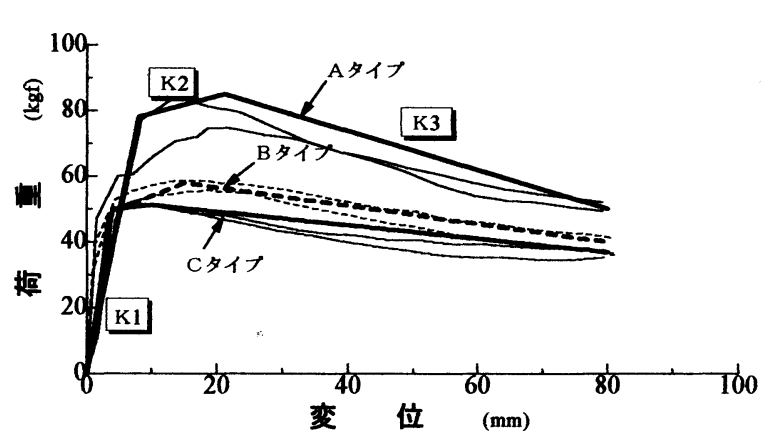

图一 17 土ばねモデル

（ただし, $1 \mathrm{kgf}=9.8 \mathrm{~N})$

表一6 土ばね定数一覧表

\begin{tabular}{|c|c|c|c|c|c|c|}
\hline \multirow{2}{*}{$\begin{array}{c}\text { PGF } \\
\text { TYPE }\end{array}$} & 変位籁囲 $(\mathrm{mm})$ & $\mathrm{K}_{1}$ & 変位範䎴 $(\mathrm{mm})$ & $\mathrm{K}_{2}$ & 変位範讲 $(\mathrm{mm})$ & $\mathrm{K}_{3}$ \\
\hline $\mathrm{A}$ & $0 \leqq \delta<8$ & 97.5 & $8 \leqq \delta<21$ & 5.4 & $21 \leqq \delta$ & -5.9 \\
\hline $\mathrm{B}$ & $0 \leqq \delta<5$ & 100.0 & $5 \leqq \delta<15$ & 8.0 & $15 \leqq \delta$ & -2.8 \\
\hline $\mathrm{C}$ & $0 \leqq \delta<4$ & 125.0 & $4 \leqq \delta<10$ & 2.2 & $10 \leqq \delta$ & -2.0 \\
\hline
\end{tabular}

ただし, $1 \mathrm{kgf} / \mathrm{cm}=9.8 \mathrm{~N} / \mathrm{cm}$

$\dot{\mathrm{U}}_{x_{\mathrm{i}}}=\dot{\mathrm{u}}_{\mathbf{x}_{\mathrm{i}}}+\ddot{\mathrm{U}}_{\mathrm{x}_{\mathrm{i}}} \cdot \Delta \mathrm{t}, \quad \dot{\mathrm{U}}_{\mathrm{y}_{\mathrm{i}}}=\dot{\mathrm{u}}_{\mathrm{yi}}+\ddot{\mathrm{U}}_{\mathrm{y}_{\mathrm{i}}} \cdot \Delta \mathrm{t}$

$\dot{\mathrm{U}}_{\mathrm{car}}=\dot{\mathrm{u}}_{\mathrm{car}}-\ddot{\mathrm{U}}_{\mathrm{car}} \cdot \Delta \mathrm{t}$

$\mathrm{Ux}_{\mathrm{i}}=\mathrm{x}_{\mathrm{i}}+\frac{\dot{\mathrm{U}} \mathrm{x}_{\mathrm{i}}+\dot{\mathrm{u}}_{\mathrm{xi}}}{2} \cdot \Delta \mathrm{t}, \quad \mathrm{Uy}_{\mathrm{i}}=\mathrm{y}_{\mathrm{i}}+\frac{\dot{\mathrm{U}} \mathrm{y}_{\mathrm{i}}+\dot{\mathrm{u}}_{\mathrm{yi}}}{2} \cdot \Delta \mathrm{t}$

$\mathrm{U}_{\mathrm{car}}=\mathrm{u}_{\mathrm{car}}+\frac{\dot{\mathrm{U}}_{\mathrm{car}}+\dot{\mathrm{u}}_{\mathrm{car}}}{2} \cdot \Delta \mathrm{t}$

ただし, $\ddot{U} x_{i}, \ddot{U} y_{i}, \ddot{U}_{c a r}$ : 時刻 $t+\Delta t$ の $i$ 質点の $x, y$ 方 向および車両の加速度, $\dot{U} x_{i}, \dot{U} y_{i}, \dot{U}_{c a r}$ : 時刻 $t+\Delta t$ の 質点の $\mathrm{x}, \mathrm{y}$ 方向速度および車両の $\mathrm{y}$ 方向速度, $\dot{\mathrm{u}}_{\mathrm{xi}}, \dot{\mathrm{u}}_{\mathrm{yi}}, \dot{\mathrm{u}}_{\mathrm{car}}$ : 時刻 $\mathrm{t}$ 質点の $\mathrm{x}, \mathrm{y}$ 方向速度および車

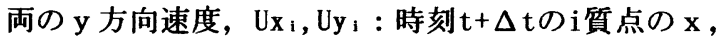
$y$ 方向の移動量, $x_{i}, y_{i}, u_{c a r}$ : 時刻 $t$ の i質点の $x, y$

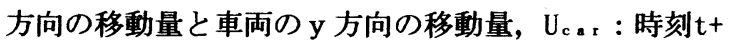
$\Delta \mathrm{t}$ 車両の $\mathrm{y}$ 方向の移動量

以上の計算方法のフローチャートを図ー15に示す. なお，計算に当たっては時間刻みを計算唄差を抑える ために $10^{-5}$ 秒とした。

\section{（3）權造パラメータの決定法}

以下に，本実験結果をシミュレートするために用い た構造パラメータの決定法について述べる.

\section{a ) PGF間の軸力ばね定数}

P G F 間の軸力は，連結用の P C 鋼線（ $\phi 5.0 ）$ を 介して伀達されるものとし，次式を用いて算出した.

$$
\mathrm{K}_{n}=\mathrm{A}_{p} \times\left(\mathrm{E}_{p} / \mathrm{L}\right)
$$

ただし, $\mathrm{K}_{n}$ ：P G F の軸力ばね定数, $\mathrm{A}_{p}$ : P C 鋼線の断 面積 $\left(=0.196 \mathrm{~cm}^{2}\right), \mathrm{E}_{p}: \mathrm{P} \mathrm{C}$ 銅線の弾性係数 $\left(=2.0 \times 10^{6}\right.$ $\left.\mathrm{kgf} / \mathrm{cm}^{2}\right)$, L: 質点間距離 $(=100 \mathrm{~cm})$.

よって, $K_{n}=0.196 \times\left(2.0 \times 10^{6} / 100\right)=3928 \mathrm{kgf} / \mathrm{cm}$ なお，P C 銅線の特性および初期緊張力 (1.5tf) を 考慮に入れ，図ー16のような弾塑性ばねを設定した. b ) 土ばね定数

土ばね定数については，土圧のみで反力が発生する 単体の静的実験結果から算出するものとした．実験 ${ }^{6)}$ で得られた荷重〜変位関係および解析モデルを图ー1 7 に示す.つまり，図中の太線のような軟化型弾塑性 モデルに置き換え, ばね定数を算出するものとした. 解析に用いたばね定数を表一6に示す.

\section{c）土のダッシュポットの娍衰係数}

一般に砂の减衰定数は0.01〜0.03といわれている ${ }^{10)}$ ので, 今回は0.03と仮定して以下のように算出した.

$$
\mathrm{C}_{\mathrm{s}}=2 \mathrm{~h} \sqrt{\mathrm{mK}_{\mathrm{s}}}
$$

ただし, $\mathrm{C}_{s}$ :土の减衰係数, $\mathrm{h}$ : 土の减衰定数 $(=0.03)$, $\mathrm{m}$ : P G F の質量, Ks:土ばね定数（初期勾配） よって,

$$
\mathrm{C}_{\mathrm{s}}=2 \times 0.03 \times \sqrt{(77.1 / 980) \times 125.0}=0.19
$$

\section{d) P G F の曲げばね定数}

P G F 間の曲げモーメントは，せん断キーを介して 伝達されるものとし, 静的実験結果から逆算して求め 


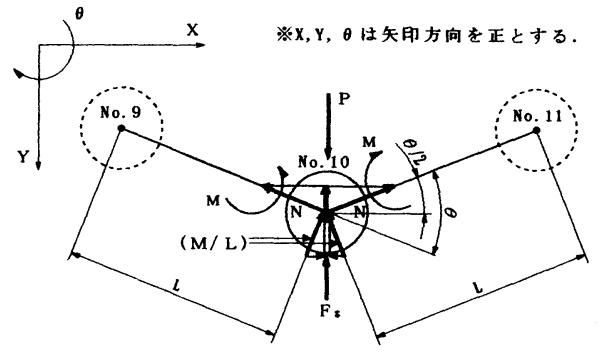

図-18y 軸方向の力のつり合い図

るものとした. すなわち, 載荷点の P G F (No. 10)の $\mathrm{y}$ 軸方向のつり合いを考えると載荷点の P G F では両 端の軸力N, 曲げモーメントMおよび背面の土ばね力F。 と載荷荷重Pの間には图ー18を参照して次のような つり合い式が成り立つ.

$$
\mathrm{F}_{y}=\mathrm{P}-\mathrm{F}_{\mathrm{s}}+2 \mathrm{~N} \sin (\theta / 2)+2(\mathrm{M} / \mathrm{L}) \cos (\theta / 2)=0
$$

ここで, 衝突点 P G F の回転角 $\theta$ と軸力ばね力Nおよ び土ばねによって発生する力 $F_{8}$ は次の式を用いて計算 することができる.

$$
\begin{aligned}
& \theta=\tan ^{-1}\left(\left(\delta_{10}-\delta_{9}\right) / \mathrm{L}\right)-\tan ^{-1}\left(\left(\delta_{11}-\delta_{10}\right) / \mathrm{L}\right) \\
& \mathrm{F}_{\mathrm{s}}=\mathrm{K}_{\mathrm{s}} \cdot \delta_{10} \\
& \mathrm{~N}=\mathrm{N}_{0}+\mathrm{K}_{\mathrm{n}} \cdot\left(\sqrt{\left(\mathrm{x}_{11}-\mathrm{x}_{10}\right)^{2}+\left(\mathrm{y}_{11}-\mathrm{y}_{10}\right)^{2}}-\mathrm{L}_{0}\right)
\end{aligned}
$$

ただし, $\delta 9,10,11$ :No. 9, 10,11の変位, № : 初期緊張 力（ここでは1.5tf）， $\mathrm{L}_{0}$ : 質点 10,11 間の初期距離 (ここでは $100 \mathrm{~cm})$.

したがって, 静的実験の結果から得られた荷重と変 位の関係（图一6はP〜 $\delta_{10}$ 関係を示しているが, 同 様にP〜 $\delta_{9}, P \sim \delta_{11}$ も実験で得られる) から式(20) によって, 曲げモーメントMと回転角 $\theta$ の関係を算出 するものとした. 图一19にその計算結果を示す. 图 -19より, 曲げばねは一定の值を超えると, 土の抵 抗力がやや弱まるために, 硬化型の弾塑性状態になる ものと思われる．なお，本解析は図中の解析モデルを 用いて行った.

\section{e）車両の局部ばね定数}

車両の衝撃緩衝効果は, 発泡スチロールを用いて模 擬したので，局部ばね定数は静的圧縮試験より得られ る荷重〜変位関係から算出するものとした. 图一20 にその実験結果と解析モデルを示す. なお, 発泡スチ ロールは圧總方向のみに作用するばねとし, 変形が復 元しようとする力は考慮しないものとした.

\section{f）車両のダッシュポットの局部娍衣係数}

車両のダッシュポットの局部堿衰係数は, 次式を用 いて算出した.

$$
\mathrm{C}_{\mathrm{car}}=2 \mathrm{~h} \sqrt{\mathrm{mK}_{\mathrm{car}}}
$$

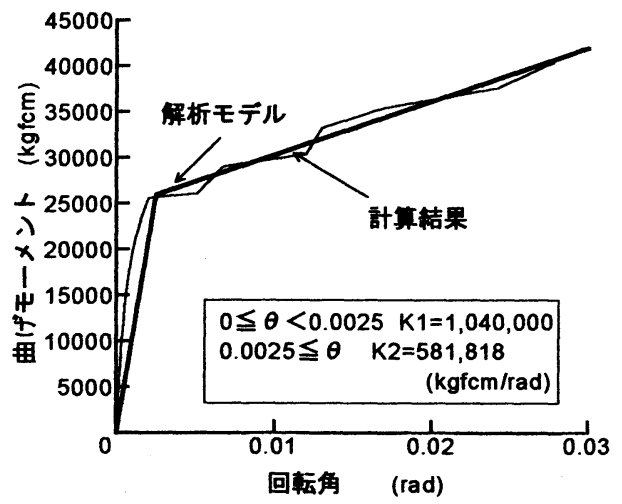

(a) Aタイプ

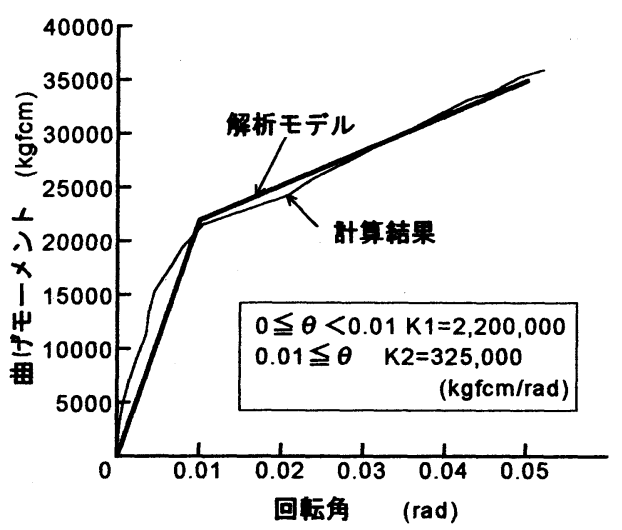

(b) Bタイプ

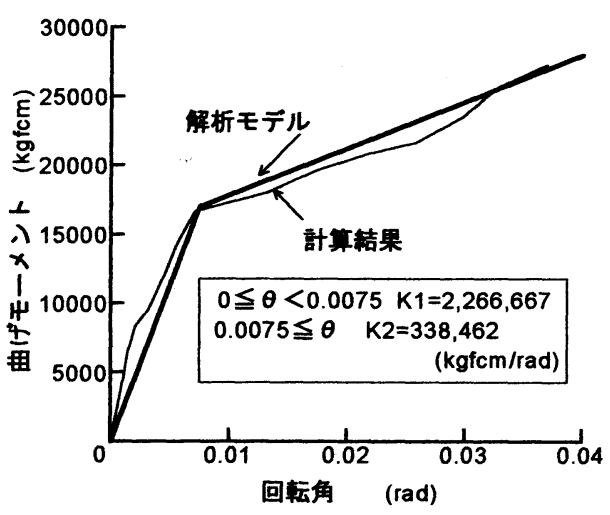

(c) Cタイプ

图ー19曲げばねモデル

（ただし， $1 \mathrm{kgfcm}=9.8 \mathrm{Ncm}$ ) 


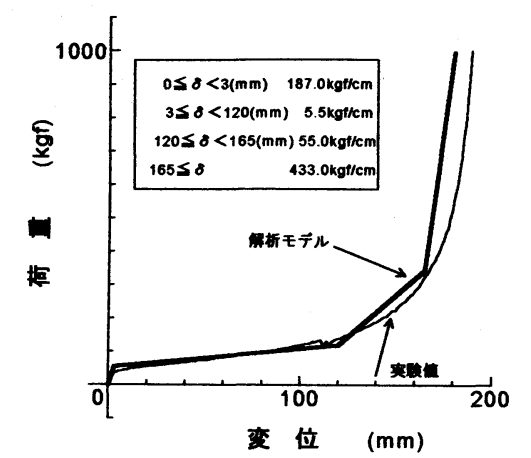

図ー20 発泡スチロールの荷重〜変位関係 (ただし, $1 \mathrm{kgf}=9.8 \mathrm{~N})$

ただし, $\mathrm{C}_{\mathrm{cs} \mathrm{r}}$ : 局部堿衰係数, $\mathrm{h}$ :局部堿衰定数 $(=0.02)$ ， $\mathrm{K}_{\mathrm{cs} r \mathrm{r}}$ : 局部ばね定数（图一20参照），m: 車両の質量. ここで，発泡スチロールのばね定数 $\mathrm{K}_{\mathrm{c}} \mathrm{a}$ は图一20に 示すように変位量に応じて異なる. また, 発泡スチロ 一ルは大変形から瞬時に解放した場合の復元応答は極 めて鈍く，高减衰な材料であることが知られている. しかし，一般に減衰定数を決定することは困難である ので, ここではK $\mathrm{ar}$ として初期の弾性係数を与えるも のとし, 局部応答のみが支配的である固定型の P G F の実験結果と解析結果を比較し, 衝突体の衝撃力の波 形がほぼ一致するように局部诚衰定数を $\mathrm{h}=0.02$ と決 定した.

よって, 局部堿衰係数は次のようになる.

$$
\mathrm{C}_{\mathrm{car}}=2 \times 0.02 \times \sqrt{(160 / 980) \times 187}=0.22
$$

\section{（4）数値計算結果}

以上のような諸定数を用いて, 各タイプについて解 析を行った結果に関して，以下に検討を行う.

图一2 1 に車両に生じた加速度の時刻歴応答を示す。 各タイプとも, 衝突から加速度の最大值までの挙動に ついては，実験値とほぼ一致していると思われる．最 大加速度発生以降の挙動については, 若干の相違が生 じている.これは, 前述したように, 発泡スチロール を圧縮方向のみに作用するばねとしたために，変形が 復元する際にP G F に作用する力を十分に表現できて いないためと思われる．また，実験的には衝突後に発 泡スチロールの局部的な破損や，吊り金具の摇れ等に より振り子が振動したりしているために, 複雑な波形 が発生している. これらの現象を, 解析で再現するこ とは困難であるが, 模擬車両の受ける最大加速度を推 察し, P G F の衝撃緩衝効果を定性的に把握するとい う本解析の観点に立てば，ほぼシミュレートできたと 思われる.

図ー2 2に衝突点のP G F の変位〜時間関俰を示す.

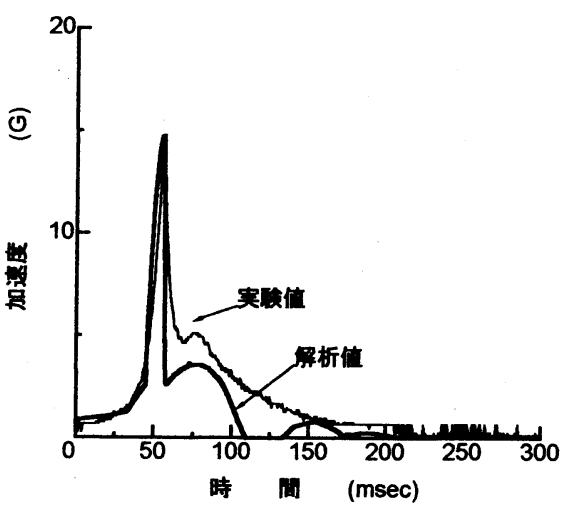

(a) Aタイプ

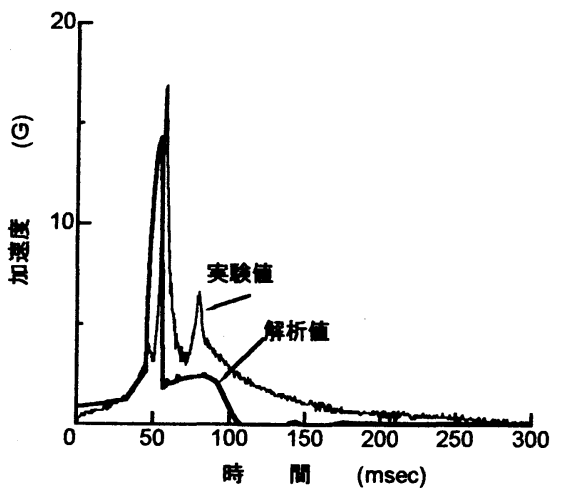

(b) Bタイプ

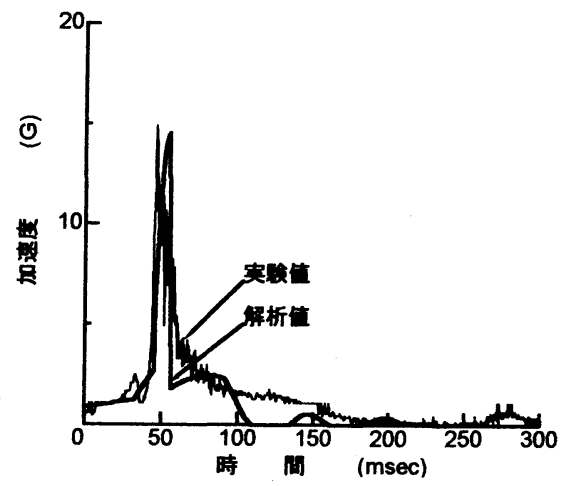

(c) Cタイプ

图一21 車両の加速度〜時間関係

Aタイプについてはほぼ一致しているが，BおよびC タイプについては, 解析値が実験結果の最大変位と残 留変位のほぼ中間の值に収束し停止している.これは, 本解析が平面的な 2 次元解析であるために，PG F の 回転変位（特に回転による復元）を十分に表現できて いないことによると思われる. 今後，単体における断 面的な 2 次元解析 ${ }^{5)}$ と組み合わせることにより，この 問題を解決していく予定である. 


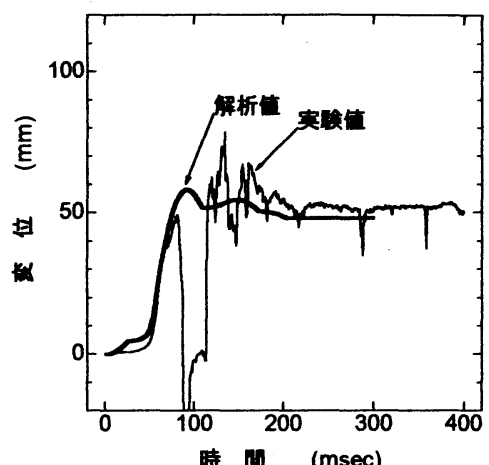

(a) Aタイプ

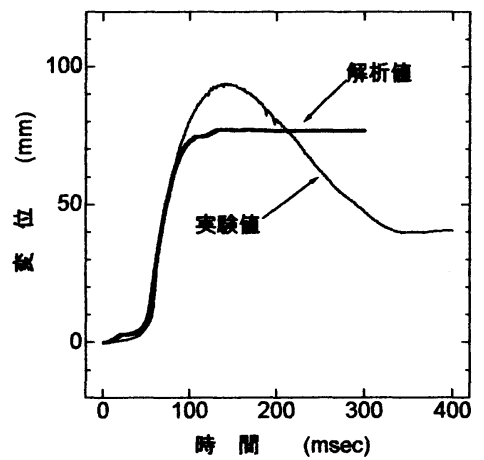

(b) Bタイプ

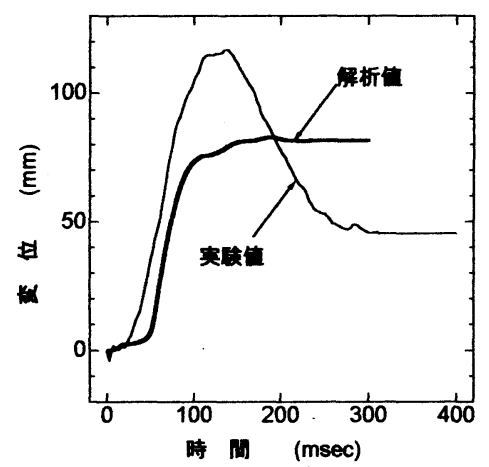

(c) Cタイプ

図-22衝突点のPGFの変位〜時間関係

図一23に各タイプの変位分布を示す．全体的に変 位の傾向についてはほぼ一致しているが，衝突点以外 の P G F の最大変位量にも若干の差が生じている.こ れも回転による変位の再現性によるものと考えられる. また, 各タイプとも, 衝突点の P G F の最大変位は, 実験値の方が大きくなっているが，これはせん断キー の破損によって, 衝突点のP G F が大きく変位したた めと思われる．模型のせん断キーは，断面寸法の関俰 で実際のものよりも強度的に弱かったために，このよ うな現象が発生したものと思われる．実車実験()にお いては，せん断キ一の破壊は認められなかったことか

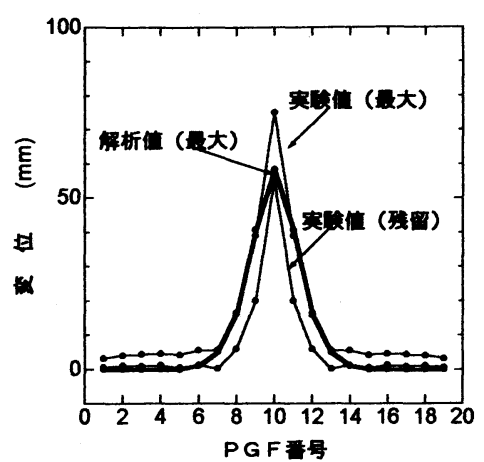

(a) Aタイプ

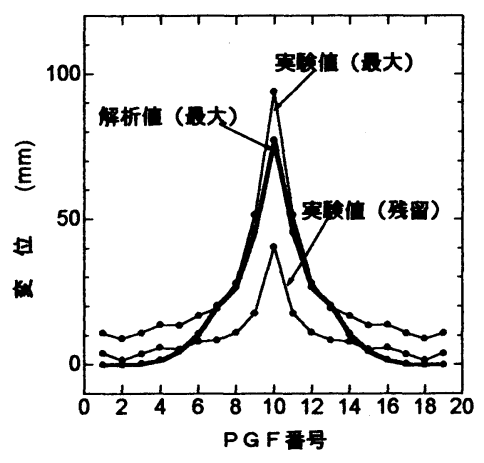

(b) Bタイプ

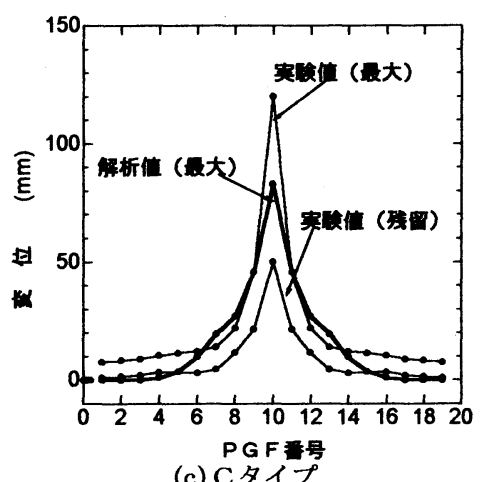

图一23 P G F の変位分布図

ら考えると，本解析值は実際の P G F の挙動にほぼ近 いのではないかと思われる.

以上の計算結果から，本解析法は実験值をほぼシミ ュレートできたものと認められる.

\section{（5）アスファルト数設の影篅に関する試算}

一般にP G F が中央分離帯に設置される場合，图一 24 に示すようにアスファルト舗装が敷設されること が想定される．このような状況では, 舗装によって P G F の移動が制御されると思われる．ここでは，本法 を用いてアスファルトを敷設した場合の影響について 


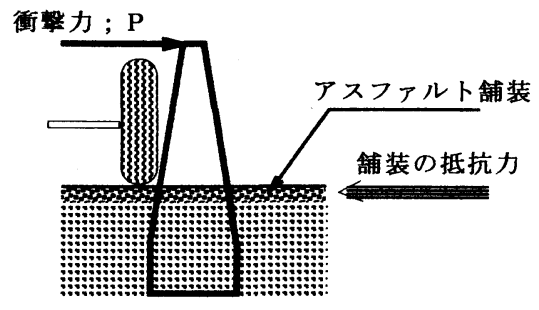

図一24 PGF 設置例

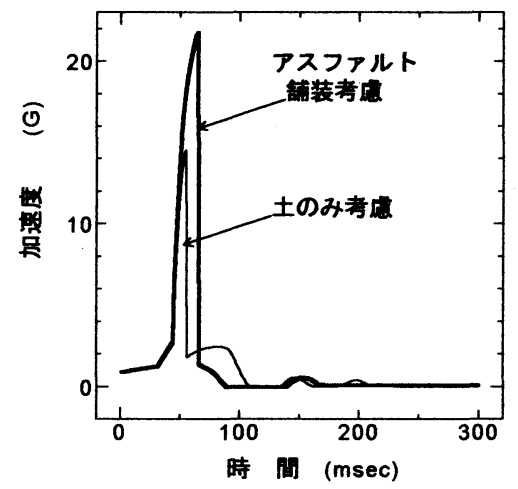

図－25 アスファルトを考慮した場合の 車両の加速度〜時間関係

解析を行い，その計算結果について考察を行うもので ある. すなわち, アスファルトのばね定数を次式によ って算出し，その影響の試算を行った。

$$
\mathrm{K}_{p \mathrm{~s} v}=\mathrm{A} \times \mathrm{E} / \mathrm{L}
$$

ただし, $K_{D}$ 、 : 舖装のばね定数 $(\mathrm{kgf} / \mathrm{cm}), \mathrm{A}$ : 舖装と P G F の接触面積 $\left(=2 \times 100=200 \mathrm{~cm}^{2}\right), \mathrm{E}:$ アスファル 卜の弾性係数 $\left(=2000 \mathrm{kgf} / \mathrm{cm}^{2}\right), \mathrm{L}:$ 舖装幅 $(\mathrm{cm})$.

一例として, 舖装幅を $100 \mathrm{~cm}$ と仮定した場合の車両 の加速度〜時間関係を図ー 25 に, またP F F の変位 分布を图ー2 6 に示す. 加速度はアスファルト舗装の 場合, 土中型の約 1.5 倍程度になる. 一方, 変位は土 中型の約 $1 / 10$ 程度に低減されることがわかる.つまり， 固定タイプに近づく傾向が認められた.この傾向は実 車実験においても確認されており, 土中型P G F の使 用法において注意を要する点であると思われる.つま り土中型P G F は, 使用箇所の特性に応じて, 例えば 変位量の制御に重点をおく場合は, アスファルト舗装 で構わないが，逆に衝撃力の緩和に重点をおく場合は， アスファルトではなく土で周囲を固めた方がよいと思 われ，施工によってその目的を達成することが可能で ある.

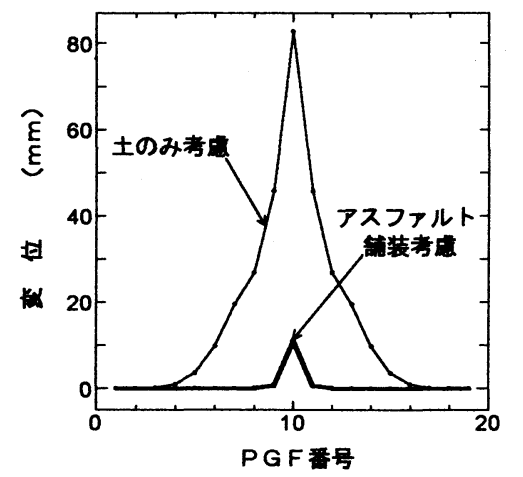

図－26 アスファルトを考虑した場合の 変位分布図

\section{（6）今後の問題点}

以下に，本解析法を一般的な構造計算および安定計 算に適用するための問題点およびこれからの課題につ いて, 若干の考察を加える.

本解析法は, 今回行った実験結果をシミュレートす るために，その定数の決定において多くの実験結果を 用いている．例えば，土ばね定数は単体の静的実験か ら得られた荷重〜変位関係を用いており，砂の特性が 限定されている.これを汎用化するためには，現場で 使用する材料の種類を数種に特定し, ばね定数を決定 するか，または砂の特性值（例えば，平板載荷試験等） からばね定数を決定する方法を提案する必要がある. このことは, P G F 間の曲げばね定数についても，同 様のことが言える．また，車両の衝突荷重〜時間関係 を実車実験で得られた值を直接入力するか, 車両をモ デル化する必要があるが, 後者は現状では困難である ために, 実車の衝突実験データを数多く入手する必要 がある.

また, 解析手法としては, 今回行った 2 次元解析か ら得られた平面的移動のデータを, 単体解析で行った 断面的 2 次元解析に代入することにより，より 3 次元 解析に近づけることが可能である.よって, 今後本方 法を実際の設計に活用していくためには，PGFの立 体挙動を解析できる方法を開発していくことが必要と 思われる.

\section{5. 結論}

P C 鋼線によって連結された土中型P G F に，車両 が衝突した場合の衝撃挙動を把握するために，振り子 式装置を用いた衝擊模型実験と剛体ばねモデルを用い た衝擊応答解析を行った. 本研究の成果を要約すると 以下のようになる.

（1）静的載荷実験における荷重〜変位関係は，形状 に関わらず硬化型の弾塑性傾向を示し, 両側にフーチ 
ングを有するAタイプは，B，Cタイプに比べて同一 変位に対して約 1.5 倍の荷重を得た.

（2）静的および衝撃栽荷実験のどちらにおいても, PGFの各タイプの形状に関わらず，中央の 5 個のP G F の変位が卓越していることが確認された.

（3）衝撃模型実験において，P G F 本体は㑉体とし て挙動しており, コンクリート本体および連結用 P C 鋼線のひずみは，それぞれコンクリートのひび割れひ ずみおよび P C 鋼棒の破断ひずみに比べ極めて小さく 安全であることが確認された.

（4）衝揧実験において, 衝突点の最大変位はC $>B$ $>\mathrm{A}$ となっているが, 残留変位はその差は小さいが $\mathrm{A}$ $>\mathrm{C}>\mathrm{B}$ となっていることが確認された.

（5）衝撃実験において，土中型P G F に衝突した車 両の加速度は, 固定型 P G F に衝突した場合に比べ約 40～60\%に低减されることが認められた. また，土中 型P G F の内，Cタイプが最も緩衝効果があることも 確認された.

（6）剛体ばねモデルによって, P G F の衝撃挙動を 比較的良くシミュレートできることを確認した.

（7）本解析法により，アスファルト舗装を用いた土 中型P G F の衝撃挙動を計算すると, 変位および車両 の衝撃加速度が定性的に固定型に近づく結果を得た。

碀辞 : 本研究を行うに当たり，PG F 協会の関倸者 に多大なご協力を得た. また, 解析手法には, 防衛大 学校土木工学科香月智助教授のご支援を得た. ここに, 謝意を表するものである.

\section{考考文献}

1）福田正 : コンクリート防護楅の現状と課題, コンクリ 一ト工学, Vol. 32, №.6, pp. 16〜25，1994年6月.

2）(財) 土木研究センター㣚性防護唡検討委員会 : 㣚性防 護槽に関する調査研究報告書（案），p. 11，1991年 3 月.

3）日本道路公団, プレキャストガードフェンス協会, 八 千代エンジニヤリング（株）：コンクリート製㣚性防 護掼プレキャストガードフェンスに関する調査検討, 1991年 12 月.

4）(財) 高速道路技術センター : 京葉道路（改策）コンク リート防護梛に関する技術検討報告書，1993年 12 月.

5) M. Okuda, K. Kobayashi, N. Ishikawa and Ohta : Impact Behavior of the Unit Body of Precast Concrete Guardfense Buried into the Soil, 3rd KERENSKY CONFERENCE, pp. 465 470, Jul. 1994.

6) 小林一隆, 奥田将樹, 石川信隆, 比留間豊 : 紘衝型 コンクリート製プレキャストガードフェンスの模型実 験に対する衝撃応答解析, 構造工学論文集, Vol. 40A, pp. 1531 1542，1994年3月.

7）江守一郎 : 模型実験の理論と応用, 技報堂出版, 1998 年.

8）川井忠彦 : 離散化極限解析法概論 培風館, 1991年.

9）戸川隼人 : 有限要素法による振動解析, サイエンス 社, 1975年.

10）F.E.リチャド.Jr，J.R.ホーN.Jr，R.D.ウッス：土と基礎の 振動, 鹿島出版会, 1986年.

\title{
IMPACT MODEL TEST AND IMPACT RESPONSE ANALYSIS OF THE PRECAST CONCRETE GUARDFENSE BURIED INTO THE SOIL
}

Kazutaka KOBAYASHI, Masaki OKUDA, Nobutaka ISHIKAWA and Toshiaki OHTA

\begin{abstract}
This paper presents experimental and analytical approaches for the behavior of the model precast concrete guardfense (so called PGF) combined with PC wire and buried into the soil against a model car. First, the impact test is performed for the model PGF by using the pendulum impact apparatus. It is found from the test that the semi-fixed type PGF (especially not having footings) has the shock softening effect rather than the fixed type PGF. It is also noted that the impact energy is shared by the displacements of 5 PGF pieces around the impacted point. Second, the impact response analysis of PGF is performed by the rigid body-spring method. It is found that the analytical approach can simulate well the experimental results.
\end{abstract}

